\title{
Analysis of Implementation "Jogja Istimewa" Based on Mobile Application Using UTAUT2 Model in Development Jogja Smart Province
}

\author{
Tea Qaula Ferbia ${ }^{1}$, Albertus Joko Santoso ${ }^{1, *}$ and Suyoto ${ }^{1}$
}

${ }^{1}$ Universitas Atma Jaya Yogyakarta, Yogyakarta, Indonesia

\section{Abstract}

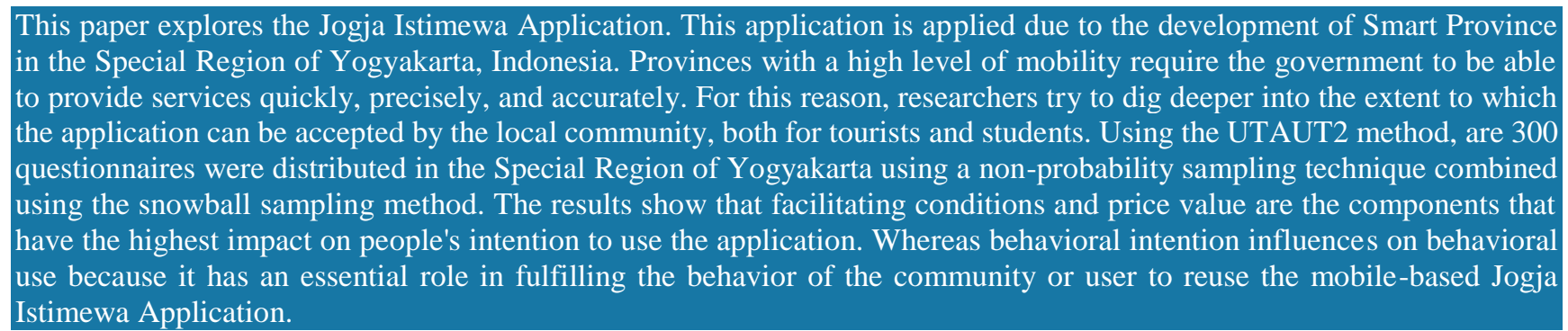

Keywords: Jogja Istimewa Application, Smart Province, UTAUT2.

Received on 02 November 2019, accepted on 01 January 2021, published on 29 January 2021

Copyright (C) 2021 Tea Qaula Ferbia et al., licensed to EAI. This is an open access article distributed under the terms of the Creative Commons Attribution licence (http://creativecommons.org/licenses/by/3.0/), which permits unlimited use, distribution and reproduction in any medium so long as the original work is properly cited.

doi: 10.4108/eai.29-1-2021.168508

\section{Introduction}

Smart City is a city planning concepts by utilizing the technological developments that will make life more comfortable with a high level of efficiency and effectiveness [1]. Smart City is also able to support the process of city development to be more anticipatory, innovative, and competitive so that it can provide a sense of comfort and more structured [3].

Seeing the enormous potential of the smart city sparked a lot of big countries in the world to implement such a system, it aims to facilitate government control, and regulation of the city was more structured. Seeing the development of these technologies in Indonesia also begins to implement smart cities both in terms of transportation, community and government, and many other sectors. Several cities in Indonesia have started to implement a smart city. One of them is Yogyakarta. Because Yogyakarta is a center of Indonesian education and tourist city, it is necessary to apply a smart city because of the other side. In addition to the objectives continue, the study of Yogyakarta is also a destination by foreign tourists. Uniquely, in Yogyakarta is not only a smart city that is run by the government, but the smart province was the one being developed by Yogyakarta. Therefore, the government of the Special Region of Yogyakarta through the Department of Communication and Information Technology tries to implement a mobile-based smart province application, that is JOGJA ISTIMEWA, making it easier for people and migrants to access information from

*Corresponding author. Email: albjoko@staff.uajy.ac.id 
the education sector, tourism and up-to-date information that occurs in Yogyakarta.

Based on this background, the author tries to review more in related application JOGJA ISTIMEWA application. So that application can be following with the conditions and needs of users. To the authors attempted to formulate the problem by the associated constraints, application implementation JOGJA ISTIMEWA are:

a. Is the public or the user having the intention to adopt or to use an application Jogja Istimewa?

b. What are the factors that influence the behavior of the application users Jogja Istimewa?

c. What are the factors that become the central pillar in the successful implementation of the application Jogja Istimewa?

d. Is the intention of the user for using the application of Jogja Istimewa has a crucial role in meeting people's behavior or the user to use the app again?

The purpose of this paper is, as follows:

a. Helping the government in conducting socialization related to Mobile-based Jogja Istimewa applications.

b. Know the value of the level of satisfaction of the community or users about the Jogja Istimewa application.

c. Find out how easily the Jogja Istimewa application is accessed.

d. Find out how much influence the use of the Jogja Istimewa application has on people or users.

\section{Literature Review}

\subsection{Research Legacy}

In this study, the researchers also tried to describe previous research related to the successful implementation of smart city applications and related methods are used. In a study conducted by Francesco Paolo Appio and his colleagues revealed that using smart city increase mobility and improve the local economy, data transparency, efficiency and effectiveness and improve resource management[2], In that study, researchers tried to understand how to recognize smart city ecosystem in terms of both technology and challenges in its implementation.

In a study conducted by Harish Kumar and his friends, they try to find solutions to overcome the obstacles in the implementation of a smart city. The study was conducted with the aim to assist the government in determining policies, the provision of services, the development of the city, as well as increase knowledge in the development of smart city[3].

In a study conducted by Madarfuksa in Latvia, researchers try to apply methods for analyzing UTAUT2 mobile and internet technology. In that study, researchers sought to explain based on several main pillars of UTAUT2, namely Performance, Effort, Facilitating conditions, technological support price, and internet experience. From those results, the researchers concluded that the use of mobile and internet technology is new and has a positive long-term impact[4].

In a study conducted in Jordan on the application of mobile banking using UTAUT2 revealed that there are several factors that influence the successful application of the mobile banking application in Jordan, namely facility conditions, social influence, effort, hedonic motivation, price, and in a study of 343 respondents stated that in the application mobile banking has a future prospect that really needs to be well studied so that it is truly in accordance with the conditions of the needs in the field [12].

\subsection{Research Model}

Based on previous studies described above, researchers try to assess the framework of this study based on the literature used in this study [5]. This method is used aims to determine the factors that have an essential role in achieving Jogja Istimewa upon the successful implementation of mobile-based applications. The variables used in this research are Expectancy Performance, Effort Expectancy, Social Influence, Facilitating Conditions, Hedonic Motivation, Price Value, and Habit. It runs by the classification variables of age, gender, the experience of using the application, and willingness to use the form. Here is a figure of research models:

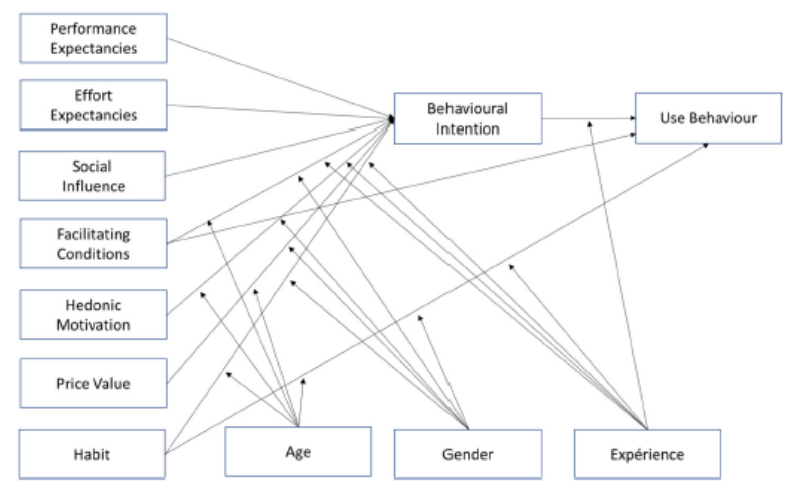

Figure 1. Unified Theory of Acceptance and Use of Technology 2 (UTAUT 2)

\subsection{Hypotheses}

In this study, the constructs used are:

\subsubsection{Performance Expectancy}

Performance expectancy aims to measure the level of confidence that the applications that are used to improve the performance and productivity of the work which will impact on the user desires to re-use information technology available[5],

\subsubsection{Effort Expectancy}

According to Venkatesh Effort Expectancy is defined as "the extent to which the ease of use of the system[6], 
Therefore, because of the specific nature Mobile banking, which requires a certain level of knowledge and skills, the hope that business can play an important role in determining the customer's intention to use these technologies. Some writers on the relevant areas of interest have been validated business expectations impact on customer's intention to use the online banking channel[5][7][8], Factors to be taken of Effort Expectancy (ie perceived ease of use) has been searched by different Mobile banking research to have an important role in predicting customer's intention to use the Mobile Banking[9], Thus, this study assumes the following hypothesis.

\subsubsection{Social Influence}

According to the model UTAUT 2, social influence characterized as "the extent to which an individual perceives that he believes should implement the new system"[6], There are also other influences that can affect a person to opt in to mobile banking as a group or family, and friends[10], In other words, information and encouragement given by the people in the surrounding customers can play a dynamic role in contributing to the awareness of customers as well as the intention of the technology[5][11], Selection of social influence as a major determinant of behavioral intention built on previous literature supporting the role of social influences affect the tendency of customers to use the online banking channel[5], As a result, this study argues that the next hypothesis.

\subsubsection{Facilitating Condition}

Facilitating conditions can be interpreted as "the degree to which an individual believes that organizational and technical infrastructure exists to support the use of the system" [6]. Usually, the use of online banking channels requires some expertise specifically for resources, users, and technical infrastructure [5]. Therefore, users can be more motivated to use the application if they will have at a certain level for resource services and support services. Also, consider the application as fitting and can be connected properly to other technologies that have been used by users. Theoretically, the role of facilitating conditions impacting on usage behavior towards using Mobile banking has the support ported by studies of different online banking[13]. Thus, the study proposes the following hypothesis:

\subsubsection{Price Value}

The relationship between the value of service and value pricing has been argued and addressed during the relevant study of online banking channels. For example, Ho and Ko (2008) empirically proven the role of perceived value in contributing intention to use internet banking customers. Likewise, the monetary value recognized as a critical influence on the adoption of internet banking, especially for potential adopters, who are more likely to receive these channels for more than one year[4]. As a result, the study proposes that:

\subsubsection{Hedonic Motivation}

Venkatesh proposed a direct correlation between the hedonic motivations and intentions of customers to use the technology. Utilities intrinsic (i.e. joy, fun, playful, entraining and enjoyment) has been put together under the concept of hedonic utility extrinsic motivation (i.e. efficiency, usability, performance expectations) in the same model[13],

\subsubsection{Habit}

Habit is established from previous experience. Habit is the extent to which someone is likely to perform the behavior as a result of learning. Furthermore, when the habit has increased, other factors will become less critical. Empirical findings from previous studies showed that habits significantly affect the individual behavioral intention to use mobile technologies such as mobile banking and mobile payments. Therefore, this study was proposed.

\subsubsection{Behavior Intention}

Behavior Intention is a user's intention to adopt the application. This can be caused by the influence of social, value pricing, condition of the facility, and some of the pillars that make an impact to participate using such applications[6].

\subsubsection{Use Behavior}

In a study done by Venkatesh and colleagues found that user behavior has a crucial role in the implementation of an application, where this can be caused by the efficiency and effectiveness able to give comfort. This pillar itself can have an impact on user intent to join or re-adopting the application[14].

\section{Result and Discussion}

This research was conducted at the KOMINFO DIY Province Office with a mobile-based population of Jogja Istimewa applications as the focus of research, namely the community and tourists who are domiciled in the Special Province of Yogyakarta.

Respondents who will be addressed from the study are people who have experience in using the mobile-based Jogja Istimewa application and those who have never used the mobile-based Jogja Istimewa application as a subject in testing hypothetical relationships with methods that have been submitted and classified by age and sex.

The determination of the number of respondents was determined using the Slovin formula. This formula is a formula used to calculate the minimum number of samples from a group or population, which is not yet clearly known. Here's the formula:

$$
n=\frac{N}{1+N e^{2}}
$$

Formula:

$\mathrm{n}=$ number of samples to be searched

$\mathrm{N}=$ number of population in an area 
$\mathrm{E}=$ tolerance limit for errors

The formula is often used when there is research on surveys with large populations. So from that, it takes a formula to find the right number of samples and a little but can represent everyone in the population.

According to information from the DIY Regional Secretariat of Yogyakarta (DIY) Bureau, the population of the city of Yogyakarta is 410,921 people (data in the form of a table attached). So after calculated by Slovin formula and using fault tolerance of $5 \%$, the sample that has represented the citizens of Yogyakarta City is 400 residents plus a tolerance of $10 \%$ from existing samples to 440 residents. A $10 \%$ addition was added because to anticipate the errors in the questionnaire contents, and the questionnaire did not return, the questionnaire was incomplete and others.

Determination of the number of respondents departs from existing research, namely, Willis (2008) and the theory refers to MacCallum et al. (1996), with a total of 100 respondents to achieve statistical power in the study. Because in SEM a sample size between 100-300 is needed, so from Slovin, there should be a total of 440 residents, and this research is enough with 300 respondents. Then the results of calculating the sample size use percentage.

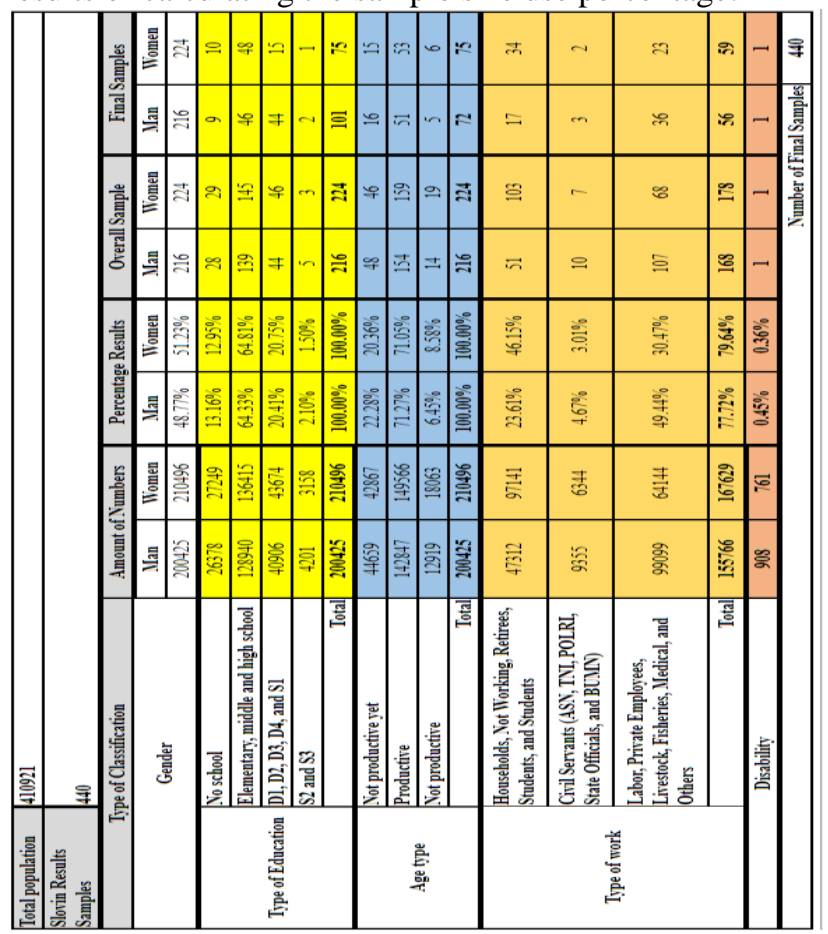

Figure 2. Calculation of Population

\subsection{RELIABILITY VALIDITY TEST COMPONENT (CR) AND AVE}

In the formal data, validity tests use AMOS version 22 of the entire list of questions that represent each of the variables tested. According to Ghozali [15], the data can be said as a valid data if the value of factor loading $>0.5$. The validity of the test results showed that all indicators of questions representing 9 variables are declared invalid by a value of $s>0.5$. Here are the results of CR and AVE validity test on this study:

Table 1. Reliability and AVE

\begin{tabular}{|c|c|c|c|c|}
\hline Variabel & Butir & \begin{tabular}{|l|} 
Factor \\
Loading
\end{tabular} & $\begin{array}{l}\text { Component } \\
\text { Reliability }\end{array}$ & AVE \\
\hline \multirow[t]{3}{*}{ PE } & PE1 & \begin{tabular}{|l|}
0,750 \\
\end{tabular} & \multirow{3}{*}{0,8134} & \multirow{3}{*}{0,5928} \\
\hline & PE2 & 0,814 & & \\
\hline & PE3 & 0,744 & & \\
\hline \multirow[t]{4}{*}{$\mathbf{E E}$} & EE1 & 0,880 & \multirow{4}{*}{0,8928} & \multirow{4}{*}{0,6761} \\
\hline & EE2 & 0,781 & & \\
\hline & EE3 & 0,807 & & \\
\hline & EE4 & 0,818 & & \\
\hline \multirow[t]{3}{*}{ SI } & SI1 & 0,775 & \multirow{3}{*}{0,8153} & \multirow{3}{*}{0,5955} \\
\hline & SI2 & 0,760 & & \\
\hline & SI3 & 0,780 & & \\
\hline \multirow[t]{4}{*}{ FC } & $\mathrm{FC} 1$ & 0,736 & \multirow{4}{*}{0,8584} & \multirow{4}{*}{0,6029} \\
\hline & $\mathrm{FC} 2$ & 0,747 & & \\
\hline & FC3 & 0,816 & & \\
\hline & $\mathrm{FC} 4$ & 0,804 & & \\
\hline \multirow[t]{3}{*}{ HM } & HM1 & 0,792 & \multirow{3}{*}{0,8652} & \multirow{3}{*}{0,6818} \\
\hline & HM2 & 0,855 & & \\
\hline & HM3 & 0,829 & & \\
\hline \multirow[t]{3}{*}{ PV } & PV1 & 0,774 & \multirow{3}{*}{0,8150} & \multirow{3}{*}{0,5949} \\
\hline & PV2 & 0,765 & & \\
\hline & PV3 & 0,775 & & \\
\hline \multirow[t]{5}{*}{ BI } & BI1 & 0,808 & \multirow{5}{*}{0,9041} & \multirow{5}{*}{0,6537} \\
\hline & BI2 & 0,836 & & \\
\hline & BI3 & 0,790 & & \\
\hline & BI4 & 0,815 & & \\
\hline & BI5 & 0,793 & & \\
\hline \multirow[t]{3}{*}{ UB } & UB1 & 0,756 & \multirow{3}{*}{0,7974} & \multirow{3}{*}{0,5675} \\
\hline & UB2 & 0,745 & & \\
\hline & UB3 & 0,759 & & \\
\hline \multirow[t]{4}{*}{ HB } & HB1 & 0,764 & \multirow{4}{*}{0,8497} & \multirow{4}{*}{0,5858} \\
\hline & HB2 & 0,740 & & \\
\hline & HB3 & 0,784 & & \\
\hline & HB4 & 0,773 & & \\
\hline
\end{tabular}

Ghozali [15] states that the test results said to be reliable if it has a value construct reliability> 0.7 and average variance extracted values $>0.5$. These test results show that the CR value for each variable is more significant than 0.7 , and the amount of each variable AVE greater than 0.5. Based on these results, we can conclude that overall these studies reliable instrument that can be used in this study

\subsection{Data Analysis SEM}

Following the model developed in this study, the data analysis tools used are SEM operated by using the AMOS application. According to Ferdinand Agusty stages of modeling and analysis using structural equation is divided into seven steps:

\subsubsection{Theoretically Model Development}

The first step in SEM models that have a strong justification has been described in chapter 3. The relationship between variables in the model is derived from the theory. Without a robust theoretical basis, SEM cannot be used.

\subsubsection{Develop a Flowchart}

The second step is to describe the framework of research in a flow diagram (path diagram). As in the figure below: 


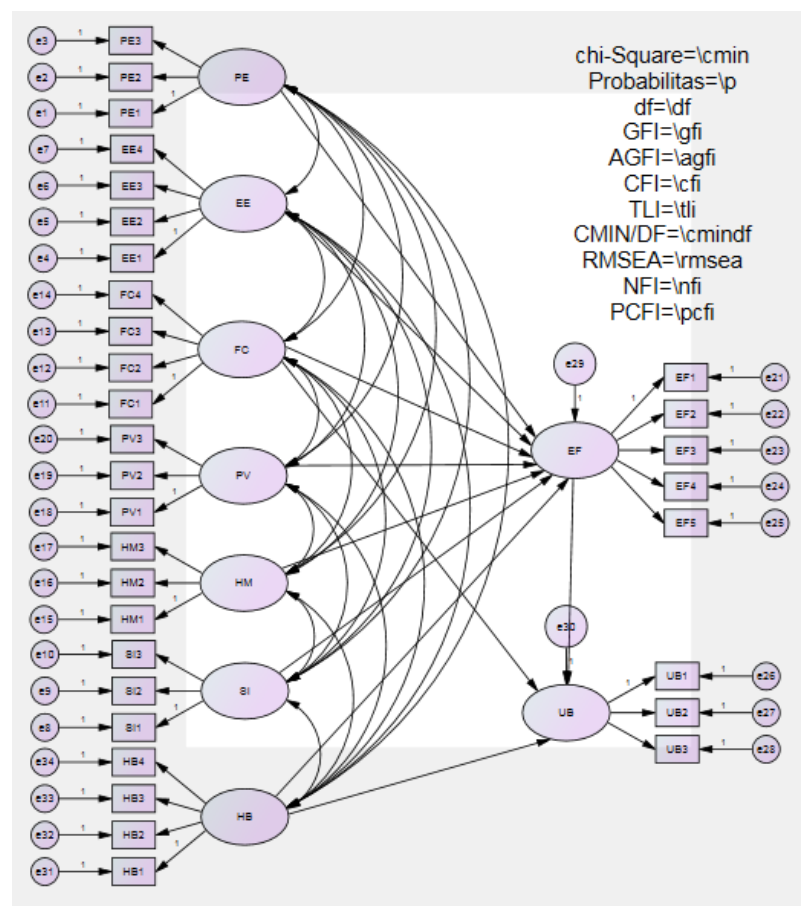

Figure 3. Flowchart

The agreement is in the depiction of the flowchart has been developed by AMOS, so use it.

\subsubsection{Changing Line Diagram Being Structural Equation}

The third step is to convert the flowchart into the equation, both structural equations and measurement model equations.

\subsubsection{Choose the Input Matrix for Data Analysis}

Step four models SEM is using the input data in the form of a matrix of covariance or correlation matrix. Data for observation can be inserted into AMOS, but AMOS will transform raw data into a first covariance matrix or correlation matrix. Estimation techniques carried out in two stages, which is the estimation of measurement model was used to test the constructs unidimensionality of exogenous and endogenous using confirmatory factor analysis techniques, and SEM estimation stage is done through a full model to see the suitability of the model and causality which was built on the model of research. The next step is to perform the measurement and estimation model, estimation equation structure.

\subsubsection{Assessing Model Identification}

Some way to see whether there is a problem of identification is to look at the results of the estimation. SEM analysis can only be done if the results of the identification of the model show that the model is included in the category of over-identified. This identification is made by looking at the value of the model created df.

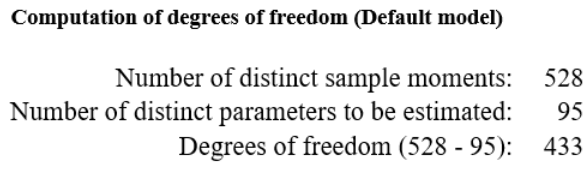

Figure 4. Df Value Model

AMOS output results that showed the value of df models of 433. This indicates that the model, including the category of over-confident because it has a positive df. Therefore, data analysis can proceed to the next stage.

\subsubsection{Evaluation of Structural Model}

The sixth step there are several Structural Model Evaluation criteria are:

\section{a. Sample Size}

The number of samples of data already met the assumptions of SEM, which is 300 data and appropriate than the recommended amount of data, the data 100-150.

\section{b. Normality}

In the output AMOS, the normality test is done by comparing the value of $\mathrm{CR}$ (critical ratio) on a critical assessment of normality at the level of $2.56 \pm 0.01$. If there is a CR value greater than the critical value of the distribution of the data is not normal univariate. While the multivariate can be seen in the last row cr under the same conditions [15].

Table 2. Normality test

\begin{tabular}{|l|llllll|}
\hline variable & min & max & skew & cr & kurtosis & cr \\
\hline HB4 & 2,000 & 5,000 & -.284 & -2005 & -.985 & -3483 \\
HB3 & 2,000 & 5,000 & -.235 & -1661 & -.912 & -3225 \\
HB2 & 2,000 & 5,000 & -.266 & -1883 & -.995 & -3519 \\
HB1 & 2,000 & 5,000 & -.381 & -2697 & -.850 & -3007 \\
UB3 & 2,000 & 5,000 & -.544 & -3850 & -.305 & -1079 \\
UB2 & 2,000 & 5,000 & -.483 & -3416 & -.600 & -2122 \\
UB1 & 2,000 & 5,000 & -.485 & -3429 & -.555 & -1962 \\
EF5 & 2,000 & 5,000 & -.143 & -1014 & -1031 & -3646 \\
EF4 & 2,000 & 5,000 & -.254 & -1795 & -.873 & -3086 \\
EF3 & 2,000 & 5,000 & -.194 & -1369 & -1143 & -4040 \\
EF2 & 2,000 & 5,000 & -.272 & -1920 & -.864 & -3053 \\
EF1 & 2,000 & 5,000 & -.208 & -1473 & -1037 & -3666 \\
PV3 & 2,000 & 5,000 & -.676 & -4780 & -.134 & -.474
\end{tabular}




\begin{tabular}{|c|c|c|c|c|c|c|}
\hline PV2 & 2,000 & 5,000 & -.619 & -4380 & -.249 & -.880 \\
\hline PV1 & 2,000 & 5,000 & -.336 & -2378 & -.624 & -2206 \\
\hline HM3 & 2,000 & 5,000 & -.486 & -3438 & -.423 & -1495 \\
\hline $\mathrm{HM} 2$ & 2,000 & 5,000 & -.448 & -3167 & -.639 & -2258 \\
\hline HM1 & 2,000 & 5,000 & -.459 & -3242 & -.567 & -2005 \\
\hline $\mathrm{FC} 4$ & 2,000 & 5,000 & -.518 & -3662 & -.446 & -1576 \\
\hline $\mathrm{FC} 3$ & 2,000 & 5,000 & -.647 & -4576 & -.211 & -.747 \\
\hline $\mathrm{FC} 2$ & 2,000 & 5,000 & -.444 & -3137 & -.608 & -2148 \\
\hline $\mathrm{FCl}$ & 2,000 & 5,000 & -.479 & -3388 & -.484 & -1712 \\
\hline $\mathrm{Si} 3$ & 2,000 & 5,000 & -.352 & -2492 & -.821 & -2901 \\
\hline SI2 & 2,000 & 5,000 & -.282 & -1993 & -1034 & -3657 \\
\hline SI1 & 2,000 & 5,000 & -.312 & -2210 & -.701 & -2480 \\
\hline EE4 & 2,000 & 5,000 & -.182 & -1289 & -.918 & -3247 \\
\hline EE3 & 2,000 & 5,000 & -.194 & -1372 & -1010 & -3572 \\
\hline EE2 & 2,000 & 5,000 & -.067 & -.476 & -.867 & -3064 \\
\hline EE1 & 2,000 & 5,000 & -.052 & -.367 & -1194 & -4222 \\
\hline PE3 & 2,000 & 5,000 & -.155 & -1094 & -.593 & -2097 \\
\hline PE2 & 2,000 & 5,000 & -.219 & -1546 & -.707 & -2499 \\
\hline PE1 & 2,000 & 5,000 & -.167 & -1179 & -.503 & -1779 \\
\hline multivariate & & & & & -.089 & -.016 \\
\hline
\end{tabular}

According to the table showing the normality test in the univariate normal distribution for the majority of critical value ratio (cr) for kurtosis and skewness, were within \pm 2.58. While in multivariate data meet normal assumptions for the value of -, 016 are within the range of \pm 2.58 .

\section{c. Outliers}

Evaluation of the multivariate outliers can be seen through AMOS output Mahalanobis Distance. The criteria used at the level of $\mathrm{p}<0.001$. The distance is evaluated using $\mathrm{X} 2$ on the degrees of freedom of the number of measurable variables used in the study. In this case, the variable's32, Then through the excel program on the sub-menu Insert Function - ChiInv enter the probabilities and the number of variables measured as follows:

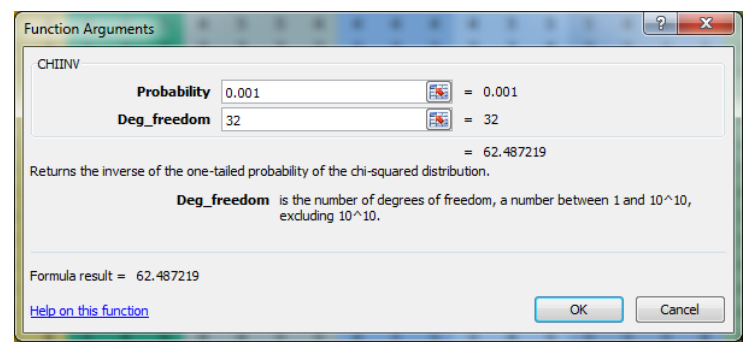

Figure 4. Multivariate outliers

The result is 62,487 .It means that all data greater than 62,487 is multivariate outliers. AMOS From the results can be seen that there is data that is larger than that value.

\section{Assessing the Feasibility Model}

After assuming SEM is done, the next step is testing by using several indices to measure the suitability of the proposed model.

Test Goodness of Fit Index

Some of the indices are:

Table 3. Test results Goodness of Fit Index

\begin{tabular}{|l|l|l|l|}
\hline Goodness of fit index & Cut-off value & Research model & \multicolumn{1}{|c|}{ Model } \\
\hline significant probability & $\geq 0: 05$ & 0,000 & marginal Fit \\
\hline RMSEA & $\leq 0: 08$ & 0,053 & Good Fit \\
\hline GFI & $\geq 0.90$ & 0.861 & marginal Fit \\
\hline AGFI & $\geq 0.80$ & 0.831 & marginal Fit \\
\hline CMIN / DF & $\leq 2.0$ & 1.843 & Good Fit \\
\hline TLI & $\geq 0.90$ & 0.937 & Good Fit \\
\hline CFI & $\geq 0.90$ & 0.945 & Good Fit \\
\hline
\end{tabular}

From table 3, it can be seen that the overall model show suitability level results mostly been well. Therefore it can be concluded that the results of the goodness of fit test using this standard model can show that the data being observed is in accordance with the theories and the model.

\subsubsection{Conducting Interpretation and Modify Model}

If the model does not fit with the data, actions following actions be taken:

1. Modifying the model by adding hyphens

2. Adding variable if the data is available

3. Reducing the variable

Modification of the model used in this research is based on the theory described by Arbuckle, which discusses how to make modifications to the model to see Modification Indices produced by AMOS 18 .

The reason researchers conducted several additional recommendations dashed lines is to minimize the chisquare value to make the model more fit. Of several steps that researchers do, AMOS output obtained as follows:

The model diagram after some modification models

After assuming SEM is done, the next step is testing by using several indices to measure the suitability of the proposed model. Some of the indices are:

From the test results, the table goodness of fit could be seen that the overall model shows a good level of fitness. Therefore, it can be concluded that the results of the goodness of fit test by using a standard model shows that the data being observed is in accordance with theories.

\section{Interpretation Estimation Model}

At this stage, the model will be interpreted and modified. Once the model is estimated, the covariant residual is small or close to zero, and distribute the residual covariance must be symmetric. The safety limit for the number of residuals generated by the model is $1 \%$. A rated residual value greater than or equal to 2.58 is interpreted as a statically significant at the $1 \%$ level and has a significant residual prediction error indicates a substantial installed indicator. 


\subsection{Hypothesis Test Results}

The statistical testing process can be seen in Table 4 below. From the data processing is well known that there is a relationship with the $\mathrm{CR}$ on show values above 1.96 for $\mathrm{CR}$ and below 0.05 for the value of $\mathrm{P}[15]$, thus it can be said that:

Table 4. Hypothesis Test Results

\begin{tabular}{|l|l|l|l|l|l|l|}
\hline No. & hypothesis & estimate & CR & P & Limit & Information \\
\hline 1 & $\begin{array}{l}\text { performance expectancy } \\
\text { effect on behavioral } \\
\text { intention }\end{array}$ & 0,154 & 2,604 & 0.009 & 0.05 & $\begin{array}{l}\text { There is an } \\
\text { effect }\end{array}$ \\
\hline 2 & $\begin{array}{l}\text { effort expectancies effect on } \\
\text { behavioral intention }\end{array}$ & 0.081 & 1,975 & 0,048 & 0.05 & $\begin{array}{l}\text { There is an } \\
\text { effect }\end{array}$ \\
\hline 3 & $\begin{array}{l}\text { social Influence effect on } \\
\text { behavioral intention }\end{array}$ & 0,296 & 2,071 & 0.038 & 0.05 & $\begin{array}{l}\text { There is an } \\
\text { effect }\end{array}$ \\
\hline 4 & $\begin{array}{l}\text { facilitating condition effect } \\
\text { on behavioral intention }\end{array}$ & 0,244 & 3.187 & 0,001 & 0.05 & $\begin{array}{l}\text { There is an } \\
\text { effect }\end{array}$ \\
\hline 5 & $\begin{array}{l}\text { hedonic motivation effect } \\
\text { on behavioral intention }\end{array}$ & -0.060 &,- 0.969 & 0.332 & 0.05 & No effect \\
\hline 6 & $\begin{array}{l}\text { price value effect on } \\
\text { behavioral intention }\end{array}$ & .543 & 3.408 & 0,000 & 0.05 & $\begin{array}{l}\text { There is an } \\
\text { effect }\end{array}$ \\
\hline 7 & $\begin{array}{l}\text { Habit effect on behavioral } \\
\text { intention }\end{array}$ & -0.012 & -0.131 & 0.895 & 0.05 & No effect \\
\hline 8 & $\begin{array}{l}\text { facilitating condition affect } \\
\text { the use behavioral }\end{array}$ & 0,010 & .111 & 0.911 & 0.05 & No effect \\
\hline 9 & $\begin{array}{l}\text { Habit affect the use } \\
\text { behavioral }\end{array}$ & 0,365 & 4,180 & 0,000 & 0.05 & $\begin{array}{l}\text { There is an } \\
\text { effect }\end{array}$ \\
\hline 10 & $\begin{array}{l}\text { Behavioral intention affect } \\
\text { the use behavioral }\end{array}$ & 0.522 & 4.729 & 0,000 & 0.05 & $\begin{array}{l}\text { There is an } \\
\text { effect }\end{array}$ \\
\hline
\end{tabular}

Based on the above table can be explained the relationship between variables:

\subsubsection{Effect of performance expectancy on} behavioral intention

Parameter estimation of the standardized regression weight coefficient obtained at 0,154 and 2,604 CR value. Testing the relationship between both variables indicate a probability value of 0.009 ( $p<0.05)$, so it can be declared if there is influence between performance expectancy with behavioral intention.

\subsubsection{Effort expectancies influence on behavioral intention}

Parameter estimation of the standardized regression weight coefficient obtained at 0.081 and $1.975 \mathrm{CR}$ value. Testing the relationship between both variables indicates a probability value of 0,048 ( $p<0.05$ ), so it can be declared if there is influence between effort expectancies with behavioral intention.

\subsubsection{The influence of social influences on behavioral intention}

Parameter estimation of the standardized regression weight coefficient obtained at 0,296 and 2,071 CR value. Testing the relationship between both variables indicate a probability value of 0.038 ( $\mathrm{p}<0.05)$, so it can be declared if there is influence between social influences with behavioral intention.

\subsubsection{Facilitating influence on behavioral intention condition}

Parameter estimation of the standardized regression weight coefficient obtained at 0.244 and 3.187 CR value. Testing the relationship between both variables indicate a probability value of 0.001 ( $\mathrm{p}<0.05)$, so it can be declared if there is influence between facilitating condition with behavioral intention.

\subsubsection{The influence of hedonic motivation to} behavioral intention

Parameter estimation of the standardized regression weight coefficient obtained at -0.060 and $-0.969 \mathrm{CR}$ value. Testing the relationship between both variables indicate a probability value of 0.332 ( $p>0.05$ ), so it can be declared if there is no influence between hedonic motivation with behavioral intention.

\subsubsection{The influence of the price value of the} behavioral intention

Parameter estimation of the standardized regression weight coefficient obtained at 0.543 and $3.408 \mathrm{CR}$ value. Testing the relationship between both variables indicate a probability value of 0.000 ( $p<0.05)$, so it can be declared if there is influence between the price value with behavioral intention.

\subsubsection{Influence on behavioral intention habit}

Parameter estimation of the standardized regression weight coefficient obtained at -0.012 and $-0.131 \mathrm{CR}$ value. Testing the relationship between both variables indicate a probability value of 0.895 ( $p>0.05$ ), so it can be declared if there is no influence of habit with behavioral intention.

\subsubsection{Effect of facilitating condition to using behavior}

Parameter estimation of the standardized regression weight coefficient obtained at 0.010 and $0.111 \mathrm{CR}$ value. Testing the relationship between both variables indicate a probability value of 0.911 ( $p>0.05$ ), so it can be declared if there is no influence between facilitating condition with user behavior.

\subsubsection{The influence of habit to use behavior}

Parameter estimation of the standardized regression weight coefficient obtained at 0,365 and 4,180 CR value. Testing the relationship between both variables indicates a probability value of 0.000 ( $p<0.05$ ), so it can be declared if there is the influence of the habit of user behavior.

\subsubsection{Effect of behavioral intention to use behavior} Parameter estimation of the standardized regression weight coefficient obtained at 0.522 and $4.729 \mathrm{CR}$ value. Testing the relationship between both variables indicate a probability value of 0.000 ( $p<0.05)$, so it can be declared if there is influence between behavioral intention to use behavior.

\section{Conclusion}

a. In the hypothesis, there are four components related to the behavioral purpose which are: performance 
expectancy, effort expectancy, social influence, and facilitating condition have a positive impact on society and the increasing desire to reuse the mobile-based application Jogja Istimewa.

b. In the hypothesis, three components related to using behavioral which are: facilitating condition, habits, and behavioral intention. Habits and behavioral intention have a positive influence on the behavior of the application users Jogja Istimewa. Still, the facilitation condition does not affect the user of the response of the mobile-based application Jogja Istimewa.

c. In these studies, show the facilitating condition and price value is the component that gives the highest impact on the intentions society or users to reuse the mobile-based application Jogja Istimewa.

d. The value of behavioral intention is positive. It means affecting use behavioral because it has an essential role in meeting people's behavior or the user to reuse the mobilebased application Jogja Istimewa.

\section{Acknowledgments}

Universitas Atma Jaya Yogyakarta partially supports this work.

\section{References}

[1] Paolo F., M. Lima, and S. Paroutis, "Technological Forecasting \& Social Change Understanding Smart Cities: Innovation ecosystems, technological advancements, and societal challenges," Technol. Forecast. Soc. Chang., No. xxxx, pp. 0-1, 2018.

[2] P. Baudier, Ammi C., and M. Deboeuf-Rouchon, "Smart home: Highly-educated students' acceptance," Technological Forecasting and Social Change, 2018.

[3] H. Kumar, MK Singh, MP Gupta, and J. Madaan, "Technological Forecasting \& Social Change Moving towards Smart Cities: Solutions that lead to the Smart City Transformation Framework," Technol. Forecast. Soc. Chang., No. April, pp. 1-16, 2018.

[4] M. Fuksa, "Mobile technologies and services development impact on mobile internet usage in Latvia," Procedia Comput. Sci., Vol. 26, pp. 41-50, 2013.

[5] AA Alalwan, YK Dwivedi, and NP Rana, "Factors Influencing the adoption of mobile banking by Jordanian bank customers: Extending UTAUT2 with trust," Int. J. Inf. Manage., Vol. 37, no. 3, pp. 99-110, 2017.

[6] V. Viswanath, GM Michael, BD Gordon, and DD Fred, "User Acceptance of Information Technology: Toward a Unified View" MIS Q., Vol. 27, no. 3, pp. 425-478, 2003.

[7] MMMA Riffai, K. Grant, and D. Edgar, "Big TAM in Oman: Exploring the promise of on-line banking, its adoption by customers and the challenges of banking in Oman," Int. J. Inf. Manage., Vol. 32, no. 3, pp. 239-250, 2012.

[8] C. Martins, T. Oliveira, and A. Popovic, "Understanding the Internet banking adoption: A unified theory of acceptance and use of technology and the perceived risk application," Int. J. Inf. Manage., Vol. 34, no. 1, pp. 113, 2014.

[9] S. Megadewandanu, Suyoto, and Pranowo, "Exploring the mobile wallet adoption in Indonesia using UTAUT2:
An approach from the consumer perspective," in Proceedings - 2016 2nd International Conference on Science and Technology-Computer, iCST 2016, 2017, pp. 11-16.

[10] M. Zhou and Y. Wu, "XML-based RDF Data management for efficient query processing," 2010, p. 1.

[11] MD Williams, NP Rana, and YK Dwivedi, "The unified theory of acceptance and use of technology (UTAUT): A literature review," Journal of Enterprise Information Management, Vol. 28, no. 3. pp. 443-448, 2015.

[12] AA Alalwan, YK Dwivedi, NP Rana, B. Lal, and MD Williams, "Consumer adoption of Internet banking in Jordan: Examining the role of hedonic motivation, habits, self-efficacy and trust," in Journal of Financial Services Marketing, 2015, vol. 20, no. 2, pp. 145-157.

[13] G. and T. Oliveira Baptista, "Understanding mobile banking: The unified theory of acceptance and use of technology combined with cultural moderators," Comput. Human Behav., Vol. 50, pp. 418-430, 2015.

[14] T. Oliveira, M. Thomas, G. Baptista, and F. Campos, "Mobile payment: Understanding the determinants of customer adoption and intention to recommend the technology," Comput. Human Behav., Vol. 61, pp. 404414, 2016.

[15] I. Ghozali, "Model Persamaan Struktural. Konsep dan Aplikasi Dengan Program AMOS 24. Update Bayesian SEM," in Model Persamaan Struktural. Konsep dan Aplikasi Dengan Program AMOS 24. Update Bayesian SEM, 2017. 